\title{
Production of Copper Powder from Ores by Elecrodeposition Process
}

\author{
Sundus Abbas Jasim Sajjad Abed Alkadhim Mohsin Maithem Ammory Jaafer \\ Metallurgy Department, College of Material Engineering, University of Babylon, Babil/Iraq \\ sundus_abbas2019@yahoo.com
}

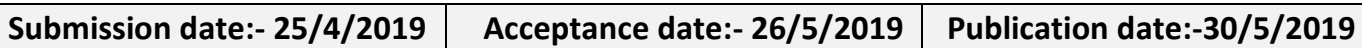

\begin{abstract}
This paper studies the preparation of Copper powder from copper sulphate aqueous solution $\left(\mathrm{CuSO}_{4} .5 \mathrm{H}_{2} \mathrm{O}\right)$, sulfuric acid $\left(\mathrm{H}_{2} \mathrm{SO}_{4}\right)$ and copper chloride $\left(\mathrm{CuCl}_{2} .2 \mathrm{H}_{2} \mathrm{O}\right)$ by using the process of electrodeposition. Process of Powder deposition has been investigated for copper powder; it is a fine layer on cathode electrode by using the value of different from time of deposition $(15,30,45$, and 60$)$ min. it is noticed the weight of the powder rises with the rise of time of depostion.

Diffractions of X-ray (XRD) revealed high crystallinity and pure copper powder not contain impurity or oxides. Optical microscopes have revealed the particles of copper have dendritic shapes. The size of Particles analyzer measured the size of a particle which is about (4.645) $\mu \mathrm{m}$.
\end{abstract}

Key word: Electrodepositon, Time of depostion, Current efficiency, Copper sulfate, Copper chloride, XRD, Particle shape, Particle size.

\section{Introduction}

Recently, powder metallurgy has rapidly grown, both in the variety of metal powder and in the quantity produced.Almost all materials can be obtained as a powder, but the method selected for production of powder depends on the specific material properties. [1]

Electodepoistion of copper is an economical processing method that allows obtaining copper of high purity in an environmentally friendly way.

The shape and size of deposited particles strongly depend on the operation of parameters of the electrodeposition process such as temperature, agitation, electrical potential, electrolyte, PH, copper concentration, nature of the substrate, additive, electrolysis time and particularly current density. [2]

Copper powder is widely used in electronics and powder metallurgy, and it can be produced by a number of methods. There are four main commercially available methods: Electrochemical, reduction of copper oxide, chemical precipitation and atomization. [3]

Nanotechnology is the most promising technology that deals with manipulation of matter on an atomic and molecular scale .Copper nanoparticles much attention due to its high electrical conductivity ,high melting point ,low electro chemical migration behavior ,excellent solderability and low material cost .The electropeosition of copper powders from electrolytic solution of copper sulphate is the mostly recommended because is most effective, environment friendly and also economical. The advantages of electrocamical method includes simple in operation, high flexibility ,less contamination,easy availabililty of equipments and no need of vacuum systems to produce pure product.[4]

The influence of organic additives on the kinetic of electrodeposition of copper ions on the surface of the polycrystalline copper electrode from the mixed aqueous-organic solutions, The possibility of obtaining ultrafine powders of copper by electrolysis in a water -isopropanol solution of cupric nitrate in the presence of additives, the organic surfactant can reduce the particle size. [5]

Several methods are used to prepare the copper, thermal reduction, mechanical attrition,chemical reduction metal vapour synthesis ,radiation methods. Eelectrolytic deposiotion is one of the most suitable, simple and low cost methods which are used for a wide range of materials ,efforts were put to produce copper nano powder using electrolytic technique .It could be possible to obtain 
near nano copper powder of $258 \mathrm{~nm}$ size using high cathode current density of $1100 \mathrm{~A} / \mathrm{m} 2$ in sulphate bath .The specific surface area and shape of the particles were found to be $23.2 \mathrm{~m} 2 / \mathrm{g}$ and irregular.. [6]

Copper ion concentration, temperature and current density was effected on the morphology and apparent density of copper powders obtained at high current density. The apparent density values of the copper powder changed with respect to their morphologies. The smaller the cauliflower -like structure of the powder particles, the lower was the apparent density of the copper powder, therefore, the apparent densities of copper powders can be controlled by changing the electrolysis parameters. . [3]

Technological properties of powder depend on their granulomerty and particle morphology. Different methods intended for clear definition of copper powders granulomertic and morphological properties. Changes of selected structure parameters and copper powder particle morphology galvanostatically deposited as a function on current density .The morphology was changed from massive to ramified 3D dendrities.[1]

This research aims to produce copper powder from ores (copper sulfates ,copper chlorides and sulphuric acids) and study the effect of deposition time, current efficiencies on the important properties (particle shape, purity and particle size of the producing powder), because the importance of copper powder in the field of industry.

\section{Experiment part}

\section{1-Electrolytic cell}

The electrolytic cell using in this research was consist of heat resistance baker glass also two copper electrodes were used as anode and cathode in the cell which have a dimension equal $(4 \mathrm{~cm})$ length, $(4 \mathrm{~cm})$ width and $(1 \mathrm{~cm})$ thickness, where purity of electrodes is $99 \%$. Electrolytic cell provided with crossbar of wood to put electrodes, where hole electrodes. Copper wires used to hang it and immersed with in solution to ensure moving location of each electrode inside the cell. Fig. (1) Shows electrolytic cell used in the electrodeposition.

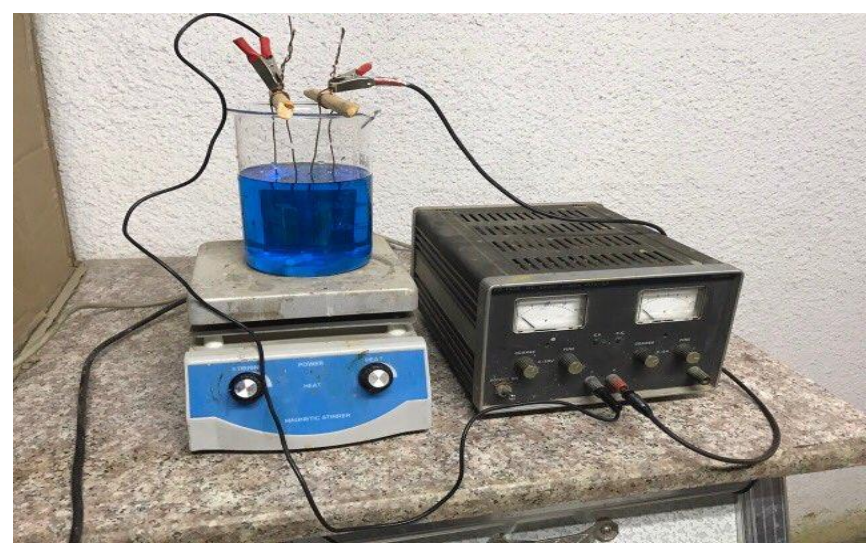

Fig. (1) Electrolytic cell used in the electrodepostion

\section{2-Aqueous Solution}

The electrolyte solution was initialized by dissolving copper sulfate (CuSO4.5H2O) with distilled water, sulfuric acid ( $\mathrm{H} 2 \mathrm{SO} 4)$ and copper chloride $(\mathrm{CuCl} 2.2 \mathrm{H} 2 \mathrm{O})$ by depending on the operating conditions.

\section{3-Electrodeposition process}

Electrodeposition process started with installs the distance between the electrode and hang of the electrodes in the specified place. Electric circuit connected with power supply to pass the electrical current at temperature $\left(30^{\circ} \mathrm{C}\right)$. As well as move of the solution during the electrodeposition, process to dispose of the bubbles of hydrogen gas that formed on the electrode surface and this is done using a magnetic stirrer. The chemical reactions are: 


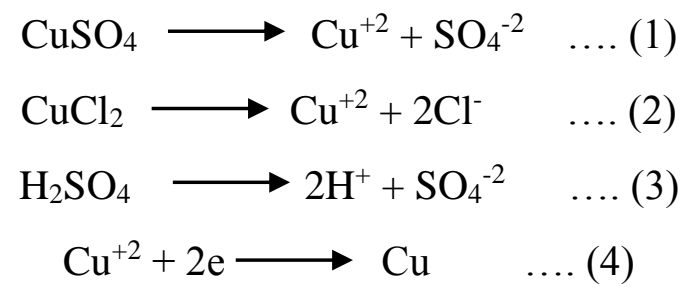

After completing the experiment time, collects the powder deposited on the cathode by using a brush and glass baker.

\section{4-Washing and drying powder}

At the beginning washing powder, was collected by distilled water and then treated with a solution of sodium bicarbonate $(0.05 \%)$ and sodium tartarate $(6 \mathrm{~g} / \mathrm{L})$. To protect the powder against subsequent oxidation after completion of the process of washing, powder filtered and dry inside the oven at temperature $\left(80^{\circ} \mathrm{C}\right)$ then weighted powder. [7]

\section{5- Effect of deposition time}

The effect of deposition time an on electrodeposition process to produce copper powder by taking different times and then note deposition process under those conditions the table (2-1) show operating conditions for deposition time

Table (2-1) operating conditions for deposition time

\begin{tabular}{|c|c|c|c|c|c|}
\hline $\mathrm{CuSO}_{4} .5 \mathrm{H}_{2} \mathrm{O}$ & $\mathrm{H}_{2} \mathrm{SO}_{4}$ & $\mathrm{CuCl}_{2} .2 \mathrm{H}_{2} \mathrm{O}$ & Current & distance & Deposition time \\
\hline $200 \mathrm{~g} / \mathrm{L}$ & $50 \mathrm{~g} / \mathrm{L}$ & $100 \mathrm{mg} / \mathrm{L}$ & $2.5 \mathrm{~A}$ & $2 \mathrm{~cm}$ & $(15,30,45,60) \mathrm{min}$. \\
\hline
\end{tabular}

\subsection{Current efficiency}

Electrolysis laws put by faraday to show the relationship between amount of electric charge pass through solution and amount of deposition on metal surface. The current efficiency was calculated from equation: - [8]

$$
\text { Current efficiency }(\%)=\mathrm{W} / \mathrm{W}^{-} * 100 \ldots(5)
$$

$\mathrm{W}^{-}=\mathrm{It} \mathrm{M} / \mathrm{nF}$

$\mathrm{W}$ : the weight of the metal deposition in experiment

$\mathrm{W}$ : the weight of the metal deposition in theory

M: Atomic weight of copper (63.54) g/mole

I: Current in ampere

$\mathrm{t}$ : time in second

F: Faraday constant (96484.coulombs per mole).

\subsection{Characterizations:}

The produced Copper powder form electrodeposition process with different deposition time was studied its morphology and the shape by optical microscope (Italy - Biolab - 1007). The powder was characterized by the diffraction of X-ray (XRD), type (Shimadzo, XRD6000, diffractometer, Japan). X-rays are generated using Copper $(\mathrm{Cu}-\mathrm{K} \alpha)$ radiation at $30 \mathrm{kV}, 40 \mathrm{~mA}$ and wavelength $(\lambda=$ $1.5406 \AA$ ), radiations for generating pattern of diffractions from a powder sample at room temperatures in a $2 \theta$ ranges of $20^{\circ}$ to $80^{\circ}$. To determine particle size of copper powder has tested by particle size analyzer (Type Better 20000. [All tests were done in Materials Engineering College laboratories Babylon University]. 


\section{3-Result and Discussion}

\subsection{Electrodeposition Process:}

In electrodeposition process used of acidic solution $(\mathrm{PH}=1.4)$, component of copper sulfate (CuSO4.5H2O), Sulfuric acid (H2SO4) and copper chlorideCuCl2.2H2O), where deposition of copper powder practically by electrolysis. Fig. (2) Show copper powder deposited on the surface of cathode electrode. The deposited copper powder form a fine layer fine powder on the surface of cathode electrode. Because high current efficiency of the produced copper powder, as shown in (Fig.3)

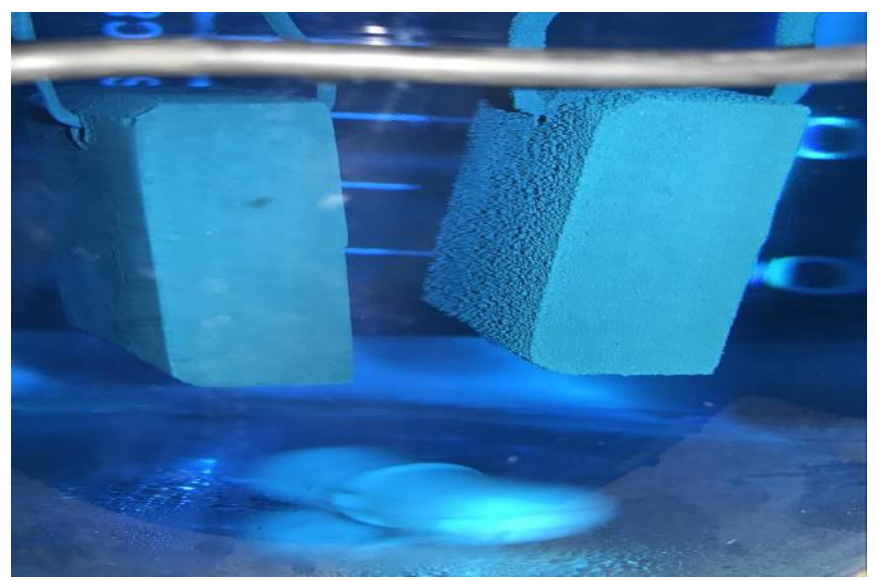

Fig. (2) Show deposited copper powder on surface of the cathode electrode

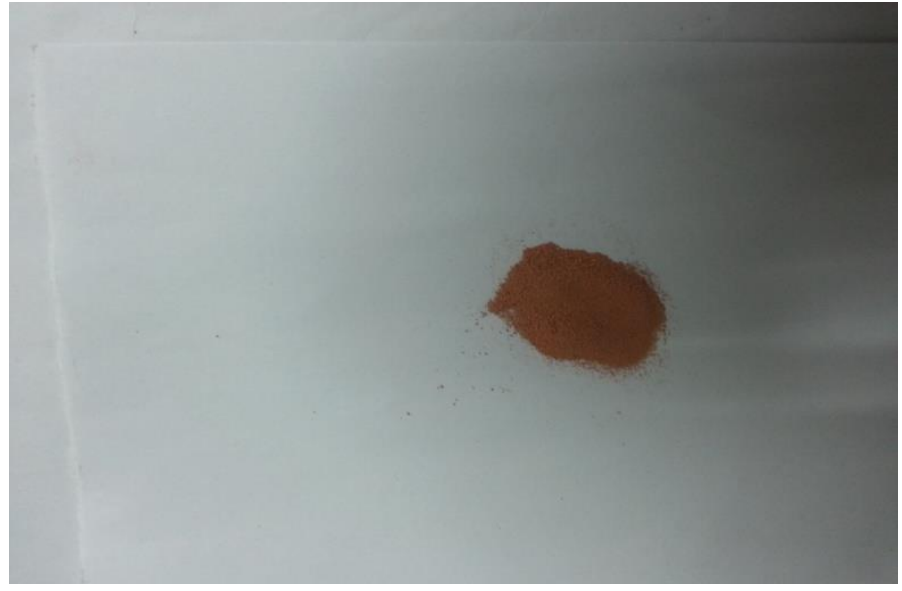

Fig. (3) Deposited copper powder after electrodepostion process

\section{3-2. Effect time of deposition:}

The time of electrodeposition is one of the important factors in the preparation of metal powders by the electrochemical process. To show effect of the powder deposition time in the electrodeposition process for copper powder, where procedure tests depending on the different values of time $(15,30,45$, 60) min. In electrolyte cell containing acidic solution from copper sulfate, sulfuric acid and copper chloride at constant temperature and distance between electrodes $(2 \mathrm{~cm})$. The results show which obtained from electrodeposition process of copper powder in electrolyte cell. The effect of time of effecting factor on weight of powder, where the weight of powder deposited during electrodeposition process increase with increase deposition time because increased current efficiency.

Fig. (4) Shows the effect of time deposition on weight of powder deposited practically, were reach current efficiency $(73.6 \%)$ at time $(60 \mathrm{~min})$ while reach to value of $(67.1 \%)$ at time $(45 \mathrm{~min})$ and decrease to the value of $(65 \%)$ at time $(30 \mathrm{~min})$ also decrease to the value $(57.9 \%)$ at time (15 $\mathrm{min})$. 


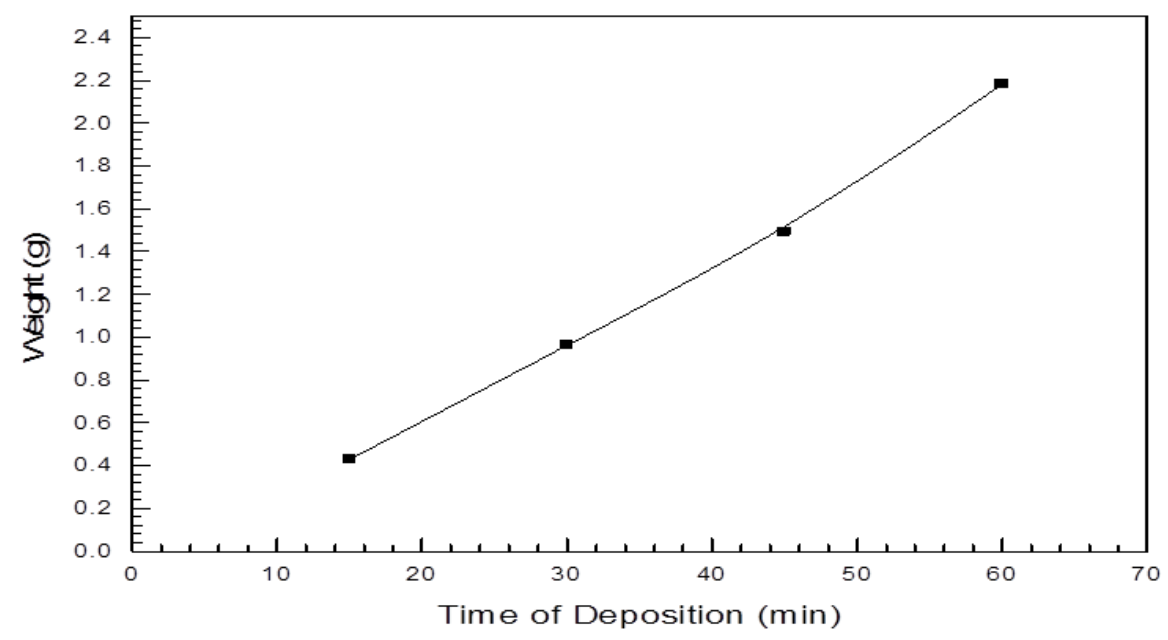

\section{Fig. (4) Show the relationship between time of deposition and weight of powder deposited practically}

Any increase of time deposition means increased deposited substance mass of copper powder. This is due an increase in the current rate of passing in the cell, lead to increase speed of the spread of metallic ions and movement towards the cathode and deposite of copper powder on surface of cathode electrode

\subsection{Particle shape:}

Optical microscope was used to determine shape of copper powder particles Fig. (5) show shape of particles of copper powder as show dendritic shape of copper powder in different of values time of depostion. Dendritic shape of copper powder identical to the results of the standard for copper powder shape in the electrodeposition process.Copper powder formed a dendritic shape because of the nucleation on the grains can occurred continuously. Those grains of copper powder and subparticles grain can be produced dendritic growth on nuclei composed on "the initial surface" and the grains themselves. [9]

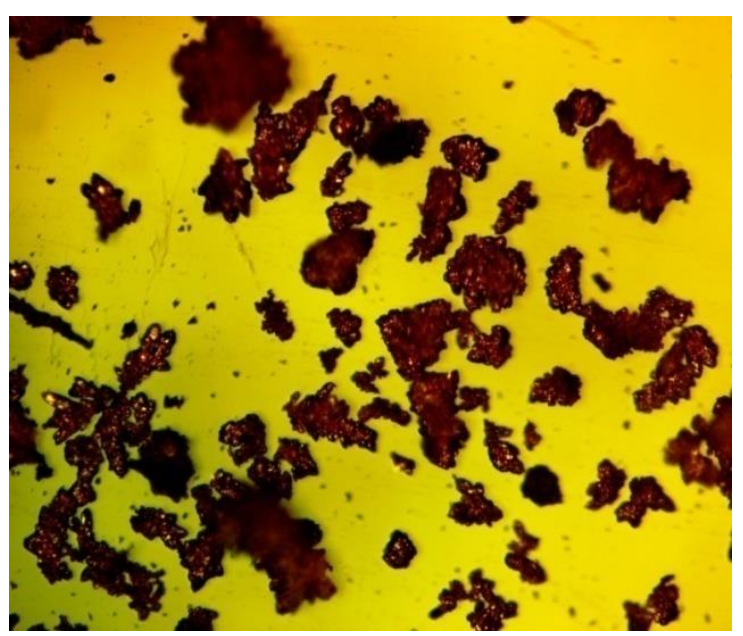

a-Particle shape at $15 \mathrm{~min}$.

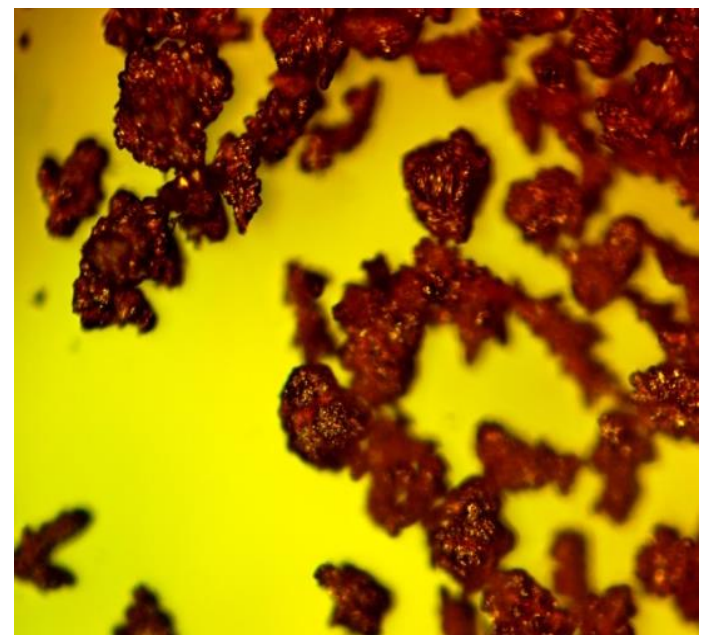

b-Particle shape at 30min. 


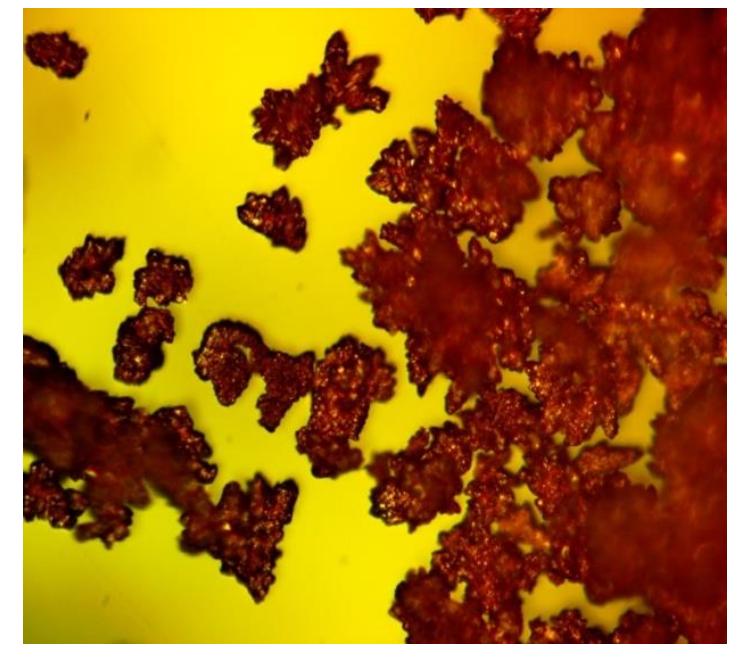

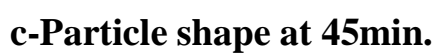

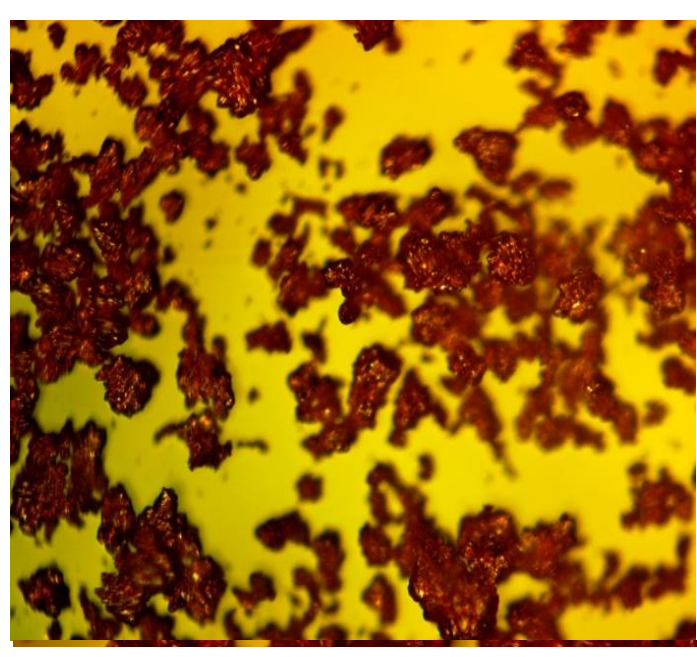

d-Particle shape at $60 \mathrm{~min}$.

Fig.(5)show dendritic shape of copper powder at different values of deposition time

\subsection{X-Ray Diffraction}

XRD can be used to describe the particles crystallinity. XRD patterns of copper powder prepared from aqueous solutions of copper sulphide, copper chloride and sulfuric acid as shown in Fig.(6) comparing with the standard JCDPS card. Observed diffraction peaks matches well with JCPDS cardsNo. 04-0836., are characterized and shown excellent crystal face centered cubic (FCC) structuresof copper and no oxides or impurities could be found. [10]

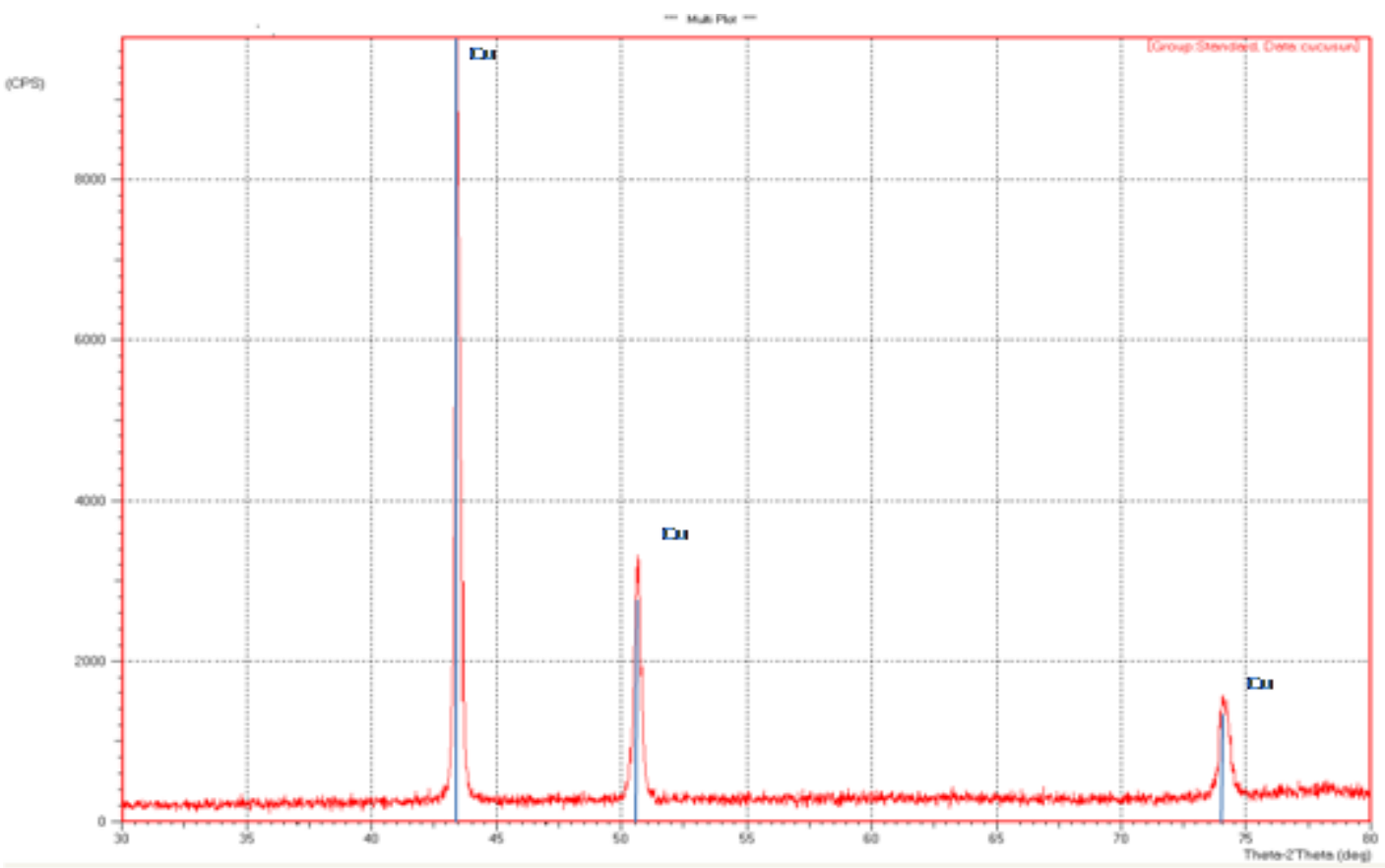

Fig. (6): X-ray diffraction of pure copper powder that produced in electrodeposition. 


\subsection{Particle size:}

The production of copper powder by electrodeposition process, calculated particle size of copper powder at time of deposition as shown average particle size and distribution of copper particles equal to $(4.645 \mu \mathrm{m})$.

these results because of the electro-crystallization of copper powder has two stages: "nucleation" and "growth". The production of powder where each nucleus was powder particles, therefore, the key for change of the relative rate of nucleating and crystal growth. was led to more disperse structure of the powder particles. [9]

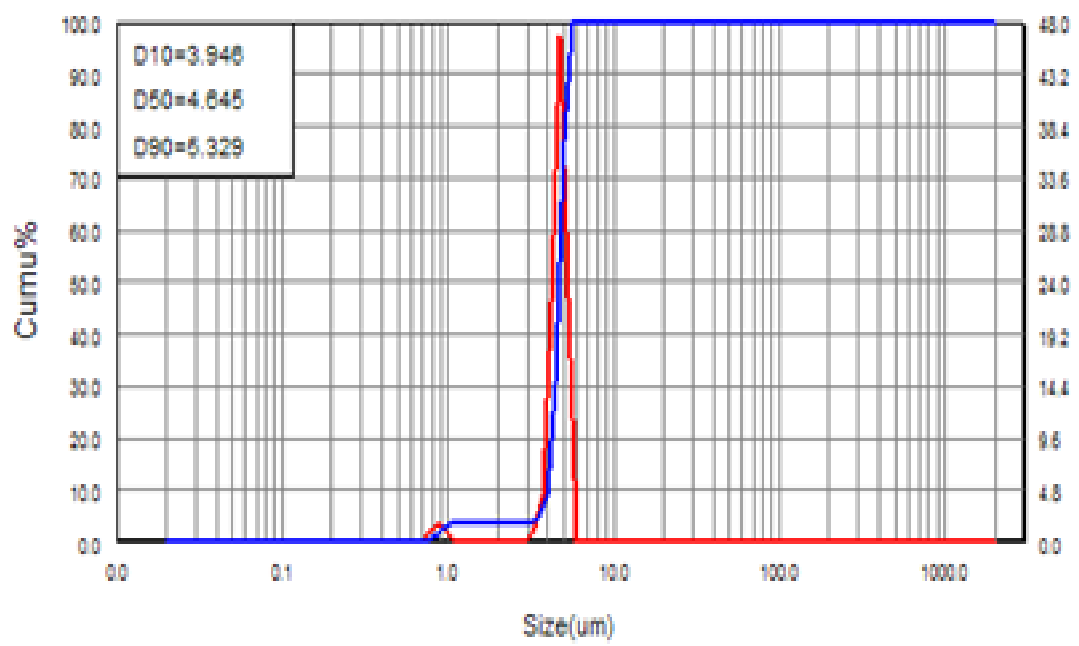

\begin{tabular}{|c|c|}
\hline Diem um & Pereent \\
\hline 0.100 & 0.00 \\
\hline 0.200 & 0.00 \\
\hline 0.500 & 0.00 \\
\hline 1.000 & 3.28 \\
\hline 2.000 & 3.72 \\
\hline 5.000 & 78.23 \\
\hline 10.000 & 100.00 \\
\hline 20.000 & 100.00 \\
\hline 45.000 & 100.00 \\
\hline 75.000 & 100.00 \\
\hline
\end{tabular}

\section{Fig. (7) Particle size distribution of pure copper powder that produced in electrodeposition.}

\section{4-Conclusions}

1- The production copper powder have highly efficiency.

2- The deposition of copper powder on the cathode electrode have a fine layer shape.

3- The increase in time of depostion of copper powder deposition leads to increase in weight of deposited copper powder.

4- Dendritic shape was formed of copper particles.

5-X-Ray diffraction had shown high crystallinity and high purity copper powder without impurities or oxide.

6- The particle size of copper powder about $(4.645 \mu \mathrm{m}$.

\section{CONFLICT OF INTERESTS.}

- There are no conflicts of interest.

\section{References:-}

[1] V.Maksimovic, Lj.Pavlovic, M.Pavlovic, M.Tomic, Characterization of copper powder particles obtained by Electrodepposition,Association of Metallurgical Engineering of Serbia, 2009, UDC:669.337:621.357.

[2] Griselda V.Gonzalez Mercado,Carlosj .Gonzalez, MarcosI.Oliva, Veronica Brunetti, Griselda A.Eimer Morphology of copper deposits obtained by metallic electrodeposition, Elsevier, procedia Materials Science 8- 2015, 635-640. 
[3] Gokhan Orhan and Gizem Guzey Gezgin, Effect of electrolysis parameters on the morphologies of copper powders obtained at hogh current densities, J.serb.chem. soc. 2012, 77(5)651-665.

[4] N.Sivashankar, S.Karthick, N.Kawin, Particle characterization of copper nanoparticles by electrochemical method ,International journal of science Technlogy and Engineering, volume3, Issueo1,2016.

[5] Baurzan B.Demeev, Akbar Dauletbay, Mical K.Nauryzaiev, The effect of organic surface -Active Additives upon the kinetics of electodepostion of Ultrafine copper powder, chemical engineering Transactions, ISBN978-88-95608-38-9, ISSN 2283-9216, Vol.47, 2016.

[6] Akansha sengar, prathviraj soni, Prepartion and characterization of near nano copper powder by Electrolytic Route, International Journal of Nonferrous Metallurgy, 2014, 3, 35-41.

[7] SundusabbasJasim, production of copper and Zinc powders by using electrochemical process, Thesis, college of engineering, Babylon University, 2006.

[8] T.j-Tuaweri, E.M.Adigio and P.P.Jombo, A study of process parameters for Zinc electrodepostion from a sulphate bath, International journal of Engineering Science Invention, volume 2, Issue 8, p.p17-24, 2013

[9] M.G. pavlovic, LS.S pavlovic, V.M. Maksimovic, N.D. Nikollic and K.I. popov, characterization and morphology of copper powder particles as a function of different electrolytic regimes, university of Belgrade, in t.J.Electrochem. Sci, 5-2010, 1862-1878.

[10]Wang Ming - Yong, Wang Zhi, Guo Zhan- chenge preparation of electrolytic copper powders with high current efficiency enhanced by super gravity filed and its mechanism, Transactions of non. Ferrous metals society china, 20- 2010, 1154-1160. 


\section{انتاج مسحوق النحاس من خاماته بعطلية الترسيب الكهربائي \\ سندس عباس جاسم سجاد عبد الكاظم محسن ميثم اموري جعفر \\ قسم هندسة المعادن، كلية هندسة المواد، جامعة بابل، بابل /العراق \\ sundus_abbas2019@yahoo.com}

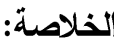

في هذا البحث يتم تحضير مسحوق النحاس من الحاليل المائية المكونة من كبريتات النحاس المائية (CuSO وكلوريد النحاس المائية الترسيب الكهربائي لمسحوق النحاس، اذ كان على شكل طبقة ناعمة يتكون على قطب الكاتود وذلك باستخدام قيم مختلفة من زمن الثرسيب (15، 30، 45، 60) دقيقه، حيث لوحظ زيادة وزن المسحوق المثرسب مع زيادة زمن الترسيب.

حيود الاثشعة السينية اظهر الحصول على مسحوق النحاس عالي البلورية ونقي أي عدم وجود الثنو ائب وليس هناك أوكسيد. أظهر المجهر الضوئي ان دقائق النحاس تمنلك شكل شجيرب، بينما فحص الحجم الحيبي بين ان الحجم الحيبي كان (4.645) مايكرومتر. الكلمات الداله: الترسيب الكهربائي، زمن الترسيب، كفاءة التيار، كبريثات النحاس المائية، كلوريد النحاس المائي، حيود الاثتعة

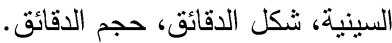

